\title{
Constructions of Zaha Hadid
}

Zaha Hadid's untimely death in March this year came as a shock to the architectural community. In this issue of arq, Gordana Fontana-Giusti reflects on Hadid's work and her 'drive towards the inventive and experimental' (pp. 95-98).

The volume of obituaries published in the global popular media in the hours and days following Hadid's death illustrated the international impact of her work. The formulation of those obituaries tended to repeat a set of tropes that pervaded reviews of her projects published during her lifetime. Katie Lloyd Thomas's 'perspective' (pp. 99-103) examines these tropes, reviewing how the public image of Hadid - the only woman in the firmament of so-called 'starchitects' - was constructed in the media. For example, what Fontana-Giusti calls 'Hadid's trade-mark prominent self-belief and strength' was usually portrayed as a divalike 'difficult' persona. Profiles in newspapers and magazines frequently began with lengthy descriptions of Hadid's clothes and physical appearance, as seems all-too-common with female celebrities. And her architectural vocabulary was often linked to essentialist ideas about curvy buildings being somehow 'feminine'.

Despina Stratigakos's book Where are the Women Architects? - reviewed in another contribution to this issue by Lloyd Thomas (pp. 178-181) - was published shortly before Hadid's death. It includes a discussion of the previous sexist media commentary that had accompanied Hadid's acceptance of the Pritzker Prize in 2005. Partly in reaction against this media treatment, partly because she was the only female 'starchitect', Hadid became a role model for anyone concerned with the gendered dimensions of contemporary practice that Stratigakos highlights. As Fontana-Giusti reflects, 'regardless of the fact that Hadid did not like to call herself a woman architect or a feminist, she has become a feminist figure'. But it was the paucity of prominent women in architecture that lent her this status more than any explicit challenge on her part to the male-dominated context in which she operated. As Lloyd Thomas reflects, 'Hadid's is just one version of a woman's success in architecture, and although the architectural forms she conceived and later built have been ground-breaking, she achieved these radical designs in the same system without challenging its structures or values.' 'There are many female role models more critical of the system', she adds, 'working beyond the professional or popular definition of the architect, while nevertheless, contributing to making the built environment a better place.'

There will be multiple interpretations of Hadid's legacy in the years to come, maybe as many as the number of people who continue to admire her work, but there is little doubt that the inheritance of her architecture will be long-lasting.

THE EDITORS 